\title{
Rice Hull Mulch Affects Germination of Bittercress and Creeping Woodsorrel in Container Plant Culture
}

\author{
James E. Altland1', Jennifer K. Boldt², Charles C. Krause1 \\ ${ }^{1}$ USDA-ARS, Application Technology Research Unit, Wooster, USA \\ ${ }^{2}$ USDA-ARS, Application Technology Research Unit, Toledo, USA \\ Email: james.altland@ars.usda.gov
}

How to cite this paper: Altland, J.E., Boldt, J.K. and Krause, C.C. (2016) Rice Hull Mulch Affects Germination of Bittercress and Creeping Woodsorrel in Container Plant Culture. American Journal of Plant Sciences, 7, 2359-2375.

http://dx.doi.org/10.4236/ajps.2016.716207

Received: September 30, 2016 Accepted: November 25, 2016

Published: November 28, 2016

Copyright $\odot 2016$ by authors and Scientific Research Publishing Inc. This work is licensed under the Creative Commons Attribution International License (CC BY 4.0).

http://creativecommons.org/licenses/by/4.0/ (c) † Open Access

\section{Abstract}

Mulches are commonly used to control weeds in container nursery crops, especially in sites where preemergence herbicides are either not labeled or potentially phytotoxic to the crop. Parboiled rice hulls have been shown to provide effective weed control when applied 1.25 to $2.5 \mathrm{~cm}$ deep over the container substrate surface. The objective of this research was to determine if weed seed placement, above or below the mulch layer, affects flexuous bittercress or creeping woodsorrel establishment. Seeds of both species were placed either above or below rice hull mulch layers $0,0.6$, 1.3 , or $2.5 \mathrm{~cm}$ deep in nursery containers with a 80 pine bark: 20 sphagnum peat moss substrate. Establishment of both weeds decreased with increasing mulch depth. Establishment of both species was generally greater from beneath the mulch compared to when seed were applied above the mulch. Light penetration through varying depths of rice hulls was determined with a spectroradiometer. Photosynthetically active radiation $(P A R)$ decreased exponentially with increasing rice hull depth, and was less than $1 \mu \mathrm{mol} \cdot \mathrm{m}^{-2} \cdot \mathrm{s}^{-1}$ beneath depths greater than $1 \mathrm{~cm}$. Germination of both species was determined in Petri dishes placed beneath varying densities of shade cloth. Flexuous bittercress germination responded quadratically to decreasing light level, but still germinated (13\%) in complete darkness after 3 weeks. Creeping woodsorrel germination was not affected by light level and was high (92\%) after 3 weeks. The role of light exclusion by rice hulls as a mechanism for controlling buried weed seed is discussed. Water retention immediately after irrigation, and for $24 \mathrm{hr}$ following irrigation, was determined for a $2.5 \mathrm{~cm}$ layer of rice hulls, sphagnum peat moss, and pine bark. Rice hulls retained less water, and dried more quickly than peat moss or pine bark. The volumetric water content of the rice hull layer is less than 0.20 $\mathrm{cm} \cdot \mathrm{cm}^{-1}$ and what has been shown necessary for plant growth. Lack of water availability in the rice hull layer is discussed as the primary mechanism of control of weed seed above the mulch layer. 


\section{Keywords}

Mulch Depth, Light, $P A R$, Seed Placement, Nonchemical Weed Control

\section{Introduction}

Many economically important weeds of field crops spread via perennating organs such as stolons, rhizomes, tubers, bulbs, or corms. Substrates of nursery container crops are isolated from each container, thus weeds cannot spread via perennating organs as they do in field soils. Weeds of nursery container crops spread primarily by seed dispersal. The most common method of weed control in nursery container crops is the use of preemergence herbicides applied to the substrate surface to inhibit weed establishment from seed. However, some crops such as hydrangea (Hydrangea macrophylla (Thunb.) Ser.), azalea (Rhododendron obtusum (Lindl.) Planch.), and many herbaceous perennials are sensitive to preemergence herbicides [1], and no preemergence herbicide is currently labeled for use on container crops inside enclosed structures such as greenhouses. The most common alternative to herbicides is the use of mulches.

Numerous mulch products have been evaluated in container crops [2]. Pine bark nuggets have been shown to provide effective control of mulberry weed (Fatoua villosa (Thunb.) Nakai) [3], prostrate spurge (Chamaesyce maculata L.), eclipta (Eclipta alba L. Hassk) [4], bittercress (Cardamine spp.), and oxalis (Oxalis stricta L.) [5]. In each of the aforementioned studies, weed control was shown to improve with increasing depth of pine bark mulch. Wilen et al. [6] showed that composted greenwaste, pecan (Carya illinoinensis (Wangenh.) K. Koch) shells, and pine (Pinus taeda L.) bark at a depth of 2.5 $\mathrm{cm}$ provided excellent control of creeping woodsorrel (Oxalis corniculata L.), northern willow herb (Epilobium ciliatum Raf.), and common groundsel (Senecio vulgaris L.), but only moderate to poor control of annual bluegrass (Poa annua L.). Ferguson et al. [7] showed that a $3.7 \mathrm{~cm}$ layer of wood chip mulches from southern redcedar (Juniperus silicicola (Small) E. Murray) and southern magnolia (Magnolia grandiflora L.) provided control of redroot pigweed (Amaranthus retroflexus L.) and large crabgrass (Digitaria sanguinalis (L.) Scop.).

Mulch products would likely be applied at or near the time of potting, and presumably would be applied to containers free of weed seed. Any weed seed introduced into the container thereafter would have to germinate and establish on the surface of the mulch product. Alternatively, mulches could be applied sometime throughout the production cycle of a crop. Containers might be hand-weeded to remove existing weeds, and then mulched. In this scenario, a large weed seed bank could be present on the substrate surface. Seed present at the time of mulch application could germinate from beneath the mulch product. A third scenario would be the carryover of weed seeds from liners into larger containers at the time of transplant. In this situation too, a seed bank present on or near the surface of the newly potted liner would have to germinate and establish through the mulch. Establishment of weed seed above and below mulch 
products has been studied previously. Cochran et al. [4] showed that placement of eclipta or prostrate spurge seed above or below 1.3 to $2.5 \mathrm{~cm}$ pine bark mulch had no effect on weed number or fresh weight accumulation. Likewise, Richardson et al. [5] showed that bittercress and oxalis establishment in containers mulched with 3.8 to 7.6 $\mathrm{cm}$ pine bark was not affected by seed placement above or below the mulch.

Parboiled rice hulls (Riceland Foods, Inc., Stuttgart, AK) are dry rice husks removed from rice grains with steam or hot water. Hereafter they will be referred to as rice hulls. Rice hulls are commercially available for horticultural use, and are currently used as a component in greenhouse and nursery substrates. Rice hulls can also be used as a container mulch. One manufacturer (Riceland Foods) recommends a rice hull mulch depth of 3.8 to $5.0 \mathrm{~cm}$ for effective weed control in container crops. Previous research has shown that rice hull mulch at a depth of $2.5 \mathrm{~cm}$ provides excellent flexuous bittercress (Cardamine flexuosa With.) and liverwort (Marchantia polymorpha L.) control when seed or propagules are disseminated onto the mulch surface [8]. The objective of this research was to determine if application of seed above or below the mulch surface affects flexuous bittercress or creeping woodsorrel establishment.

\section{Materials and Methods}

\subsection{Weed Germination Above or Beneath Rice Hull Mulch}

On 17 Jan. 2014, 15-cm diameter and tall containers (trade-gallon) were filled with an 80 pine bark : 20 sphagnum peat moss substrate to within $2.5 \mathrm{~cm}$ of the container top. It was established that a $2.5 \mathrm{~cm}$ deep layer of rice hulls (Riceland Foods, Inc., Stuttgart, $\mathrm{AK}$ ) on the substrate surface would weigh $46 \mathrm{~g}$. Containers were randomly assigned to receive rice hulls at a depth of $0,0.6,1.3$, or $2.5 \mathrm{~cm}$ by weighing $0,11.5,23$, or $46 \mathrm{~g}$ of rice hulls and spreading them evenly over the surface. Half the containers were seeded with flexuous bittercress and the other half with creeping woodsorrel. These two weeds were selected as the test species due to their prevalence in greenhouse and nursery container crops. Weed seed were either placed on the substrate surface prior to mulch application, or on top of the mulch surface following mulch application. For containers receiving weed seed below the mulch layer, 40 seeds were applied to the substrate surface prior to mulch application. For containers receiving weed seed above the mulch surface, 10 seeds were applied to the container surface each week for 15 weeks throughout the course of the experiment. There were six single pot replications for each weed species, seed placement, and mulch depth combination. Containers were arranged in a completely randomized design with the two weed species randomized separately.

Containers were placed in a glass-covered greenhouse in Wooster, $\mathrm{OH}$, and received natural photoperiod with heat and cool set-points at $20^{\circ} \mathrm{C}$ and $23.9^{\circ} \mathrm{C}$, respectively. Containers received overhead irrigation consisting of city tap water injected with a commercial complete fertilizer with micronutrients (Jack's $20 \mathrm{~N}-4.4 \mathrm{P}-16.6 \mathrm{~K}-0.15 \mathrm{Mg}$ 0.02B-0.01Cu-0.1Fe-0.05Mn-0.01Mo-0.05Zn, JR Peters, Inc., Allentown, PA) at a concentration of $100 \mathrm{mg} \cdot \mathrm{L}^{-1} \mathrm{~N}$. Irrigation was run twice daily for $7 \mathrm{~min}$ each cycle, so that each plot received approximately $1 \mathrm{~cm} \cdot \mathrm{d}^{-1}$ water. Irrigation was provided daily through- 
out the experiment.

Weed number and shoot fresh weights were determined 4, 8, and 12 weeks after potting (WAP). Because the number of seed applied, and the timing of seed application differed between containers in which seed were applied above or below the mulch, the treatment factor of seed placement is discussed but was not compared statistically (with the exception of data collected 4 WAP and \% germination). Weed number were arcsine-square root transformed for analysis, although actual data are presented. Data were subjected to repeated measures analysis of variance (ANOVA) using the general linear model (GLM) procedure in SAS. Regression analyses were conducted with orthogonal contrast statements within the GLM procedure. The least significant difference (LSD) for treatment means was calculated using Fisher's protected LSD test where $\alpha=0.05$.

\subsection{Light Penetration through Rice Hulls}

A spectroradiometer (PS-200, Apogee Instruments, Logan, UT) was placed within an opaque, black, 12 L nursery container (\#3 Nursery Supplies, Chambersburg, PA). An initial spectral scan of photosynthetically active radiation $(P A R, 400$ to $700 \mathrm{~nm}$ ) was recorded outdoors (Toledo, OH) on 28 Aug. 2014 at mid-day on a sunny day. A 24-cm diameter glass pie plate (Pyrex, World Kitchen LLC, Rosemont, IL) was placed over the top opening of the container where the outer edge of the plate rested on the rim of the container while the bottom of the plate nested within. The sides of the pie plate were covered with black electrical tape to prevent light from reflecting or refracting through the edges of the plate. Another spectral scan was taken to provide the percent light transmission through the plate. Rice hulls were placed in the plate at depths ranging from 0 to $2.5 \mathrm{~cm}$. It was established that a $2.5 \mathrm{~cm}$ layer of rice hulls in the glass plate weighed $154.6 \mathrm{~g}$. The mass of rice hulls needed for each depth was subsequently calculated based on this rice hull depth to weight ratio $(2.5 \mathrm{~cm}: 154.6 \mathrm{~g})$. Spectral scans were taken from approximately $5 \mathrm{~cm}$ beneath the glass plate filled with varying levels of rice hulls using the spectroradiometer. Five scans were recorded for each rice hull depth, using a different pre-weighed batch of rice hulls for each scan. The order in which they were taken was blocked in time and completely randomized within each block. Spectral scans of full sunlight and with the empty glass plate were taken at the end of the measurement period and averaged with the initial scans. The intensity of full sunlight at the beginning and end was 1880 and $1790 \mu \mathrm{mol} \cdot \mathrm{m}^{-2} \cdot \mathrm{s}^{-1} P A R$, respectively. Light intensity for $P A R$ and each waveband of light passing through the rice hull depths was subjected to ANOVA and means separation. Data were also fit to exponential functions in the form of $\mathrm{I}=\mathrm{a}+\mathrm{be}^{-\mathrm{cx}}$ where $\mathrm{x}=$ mulch depth, $\mathrm{I}=$ intensity, the sum $\mathrm{a}+\mathrm{b}$ equals the maximum light intensity when mulch depth is 0 , and $c$ is a scaling factor (Figure 1 ).

\subsection{Germination Response to Irradiance Intensity}

Flexuous bittercress and creeping woodsorrel germination in response to irradiance intensity was determined in a growth chamber (BDR16, Conviron, Winnipeg, CN) using 

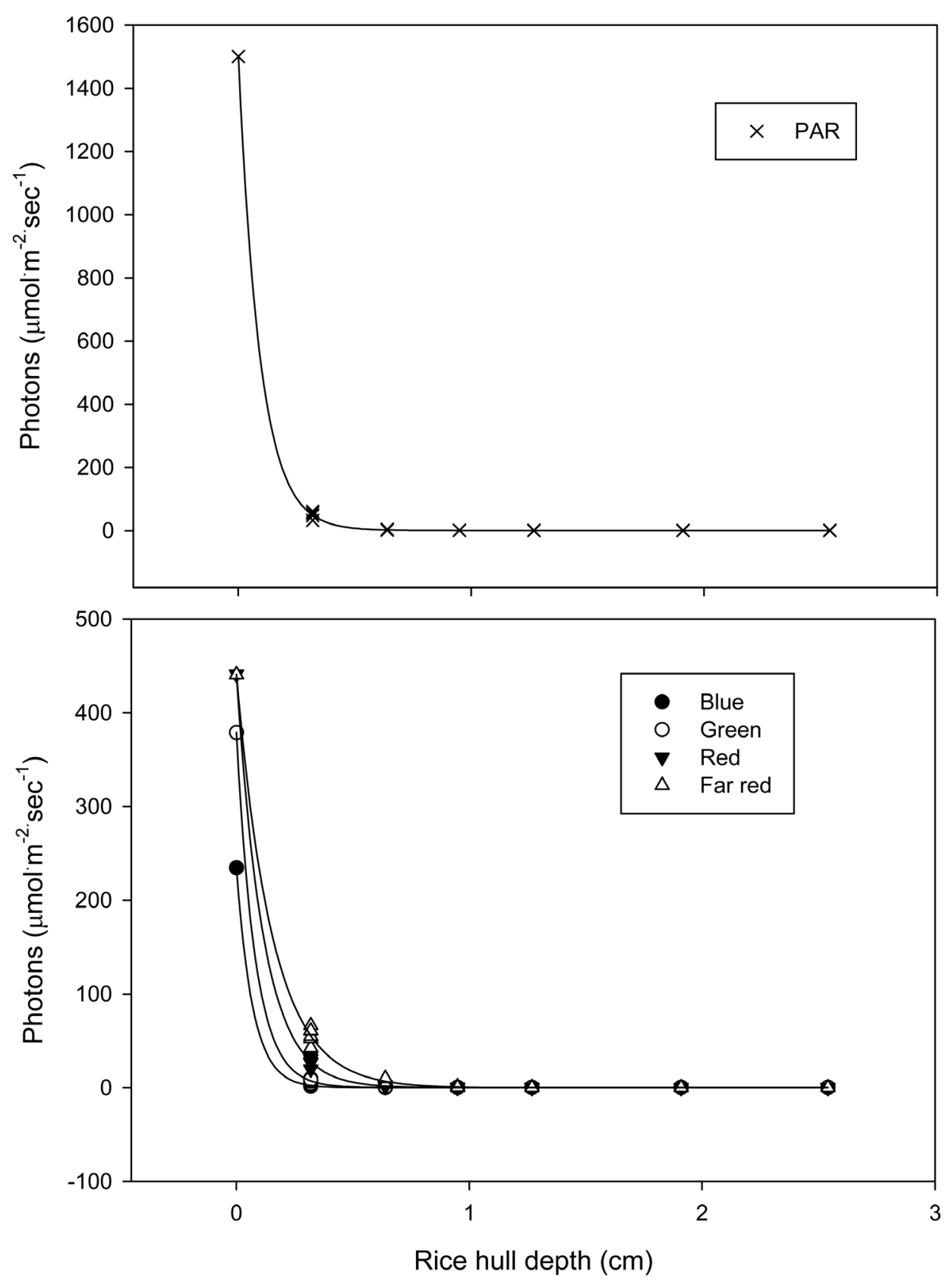

Figure 1. Penetration of light through varying depths of a rice hull mulch. Photosynthetically active radiation (PAR, 400 to $700 \mathrm{~nm}$ ) is displayed in the chart above, and blue (450 to $499 \mathrm{~nm}$ ), green (500 to $569 \mathrm{~nm}$ ), red (620 to $699 \mathrm{~nm}$ ), and far red (700 to $799 \mathrm{~nm}$ ) light displayed in the chart below. PAR $=0.99+1515.9 \mathrm{e}^{(-10.8 \mathrm{x})}, \mathrm{R}^{2}=0.9998$; Blue $=0.066+237.87 \mathrm{e}^{(-14.3 \mathrm{x})}, \mathrm{R}^{2}=0.9999$; Green $=0.323+383.3 \mathrm{e}^{(-12.5 \mathrm{x})}, \mathrm{R}^{2}=0.9999$; Red $=0.219+445.0 \mathrm{e}^{(-8.7 \mathrm{x})}, \mathrm{R}^{2}=0.9994$; Far red $=$ $-0.057+443.7 \mathrm{e}^{(-6.5 \mathrm{x})}, \mathrm{R}^{2}=0.9982$. For all equations, $\mathrm{n}=31$.

Petri dishes $(95 \mathrm{~mm} \times 15 \mathrm{~mm}$ ). The growth chamber was programmed to provide a constant $20^{\circ} \mathrm{C}$ air temperature, $10 \mathrm{hr}$ photoperiod, and $30 \%$ relative humidity (RH). Irradiance was provided by cool-white fluorescent lamps (FT2T8/TL841/HO, Philips Lighting, Somerset, NJ). An agar base was made using $15 \mathrm{~g} \cdot \mathrm{L}^{-1}$ granulated agar in a 
modified Hoagland solution (in mM: 7.5 N, $0.5 \mathrm{P}, 3 \mathrm{~K}, 2.5 \mathrm{Ca}, 1 \mathrm{Mg}, 1 \mathrm{~S}, 0.071 \mathrm{Fe}, 0.009$ $\mathrm{Mn}, 0.0015 \mathrm{Cu}, 0.0015 \mathrm{Zn}, 0.045 \mathrm{~B}, 0.0001 \mathrm{Mo}, 0.024 \mathrm{Cl}, 0.0002 \mathrm{Na}$ ). The agar was autoclaved for $20 \mathrm{~min}$, then $25 \mathrm{~mL}$ was poured into each Petri dish. Ten seeds of each weed were placed onto the agar media so that the seed from each species was confined to one half of the dish. Petri dishes were exposed to six different light treatments by placing them individually within a $2.5 \mathrm{~cm}$ tall section of $10 \mathrm{~cm}$ o.d. black ABS pipe (Charlotte Pipe Products, Monroe, NC). One group of Petri dishes was placed inside of uncovered $\mathrm{ABS}$ pipe sections. Other groups of ABS pipe sections were covered with a single layer of $30 \%$ shade cloth, a single layer of $63 \%$ shade cloth, two layers of $63 \%$ shade cloth, or four layers of $63 \%$ shade cloth (DeWitt Woven Shade Cloth, Sikeston, $\mathrm{MO}$ ). Shade cloth was attached to the top of the ABS pipe and kept taut and in place with a zip tie (Panduit Co., Tinley Park, IL). A final group was covered with opaque foil tape (3M, St. Paul, MN) to exclude $100 \%$ of the light. The actual light reduction beneath each shade treatment was measured with a spectroradiometer and determined to be $0 \%$, $22 \%, 61 \%, 88 \%, 99.9 \%$ and $100 \%$ shading, respectively, which corresponded to 336.3 , $261.6,131.5,41.3,0.3$, and $0 \mu \mathrm{mol} \cdot \mathrm{m}^{-2} \cdot \mathrm{s}^{-1} P A R$, respectively. There were ten replications per shade treatment arranged in a randomized complete block design within the growth chamber. Petri dishes from five replications were destructively harvested to count the number of germinated seed 1 and 3 weeks after seeding (WAS). Weeds were considered germinated if both roots and cotyledons were visible with a hand lens. Data were arcsine-square root transformed for analysis, although actual data are presented. Transformed data were subjected to ANOVA and means separation using SAS (Version 8, SAS Institute, Cary, NC). The experiment was repeated.

\subsection{Water Loss from Mulch Layers}

Two-piece, polyvinyl chloride Buchner funnels $(13.1 \mathrm{~cm}$ i.d., $6.6 \mathrm{~cm}$ tall, Fisher Scientific, Waltham, MA) were filled with a $2.5 \mathrm{~cm}$ layer of rice hulls, sphagnum peat moss (Fafard, Agawam, MA), or pine bark (Buckeye Resources, Dayton, OH). It was established that a $2.5 \mathrm{~cm}$ layer of rice hulls, peat moss, and pine bark weighed 46, 70, and 130 g, respectively. These weights were used to uniformly apply the same mass of each mulch material to replicate funnels. A subsample of each mulch material was weighed, oven dried at $72^{\circ} \mathrm{C}$ for $4 \mathrm{~d}$, and weighed again to determine percent moisture content of the rice hulls, peat moss, and pine bark, which was $7.6 \%, 71.2 \%$ and $69.1 \%$, respectively. Each mulch-filled funnel was weighed $\left(\mathrm{W}_{\mathrm{i}}\right)$ and placed on a greenhouse bench equipped with an overhead irrigation system with fixed pattern nozzles (Rain Bird 5H, Rain Bird Corp., Azusa, CA). Each funnel was placed over a $400 \mathrm{~mL}$ glass jar (Fisher Scientific) so that all irrigation water passing through the mulch layer would collect in the jar beneath, and furthermore, only water passing through the funnel (and no other extraneous irrigation water) would drain into the jar. The irrigation system was run for $10 \mathrm{~min}$, resulting in an application of approximately $1.3 \mathrm{~cm}$ of water. The funnels were weighed after the irrigation ceased and funnels stopped dripping $\left(\mathrm{W}_{0}\right)$. The funnels were weighed again 1,4 , and $24 \mathrm{hr}$ after the irrigation event $\left(\mathrm{W}_{1}, \mathrm{~W}_{4}\right.$, and $\mathrm{W}_{24}$, respec- 
tively). The volume of water passing through the mulch and into the jar beneath was measured $(\mathrm{V})$. The percent of water passing through the mulch layer in each funnel was calculated as $\mathrm{V} /\left(\mathrm{W}_{0}-\mathrm{W}_{\mathrm{i}}+\mathrm{V}\right)$. Volume of water passing through the mulch layer was expressed as a percent to correct for variation in the volume of applied water due to non-uniformity of the irrigation system. The mass of water retained in the mulch layer at 1,4 , and 24 hours was calculated as $\mathrm{W}_{1}-\mathrm{W}_{\mathrm{i}}, \mathrm{W}_{4}-\mathrm{W}_{\mathrm{i}}$, and $\mathrm{W}_{24}-\mathrm{W}_{\mathrm{i}}$, respectively. The mulch filled funnels remained in place on the greenhouse bench where they were irrigated daily. There were six replications per mulch material placed in a completely randomized design. The process described above to measure the volume of water passing through the mulch, and the mass of water retained in the mulch layer over the course of $24 \mathrm{hr}$ was repeated at 2 and 4 weeks after the initial measurement. Data were subjected to ANOVA and Fisher's protected means separation using SAS. The experiment was repeated.

\section{Results}

\subsection{Weed Germination Above or Beneath Rice Hull Mulch}

At $4 \mathrm{WAP}$, seed placement and rice hull depth interacted to affect flexuous bittercress numbers $(P<0.0001$, Table 1$)$. Weed number decreased linearly and quadratically with increasing rice hull depth in containers seeded above the mulch, and decreased linearly for those seeded below the mulch. Across all rice hull depths, contrast analysis (not presented in Table 4) showed that flexuous bittercress numbers were greater in con-

Table 1. Flexuous bittercress (Cardamine flexuosa) numbers and shoot fresh weight 4, 8, 12, and 16 weeks after potting (WAP) in containers with 0 to $2.5 \mathrm{~cm}$ rice hull mulch. Weed seeds were placed either above or below the mulch layer. Weed seed placed above the mulch were applied at 10 seed per pot per week. Weed seeds placed below the mulch were applied at 40 seeds per pot prior to mulching.

\begin{tabular}{|c|c|c|c|c|c|c|c|c|c|c|c|c|}
\hline $\begin{array}{c}\text { Seed } \\
\text { placement }\end{array}$ & $\begin{array}{c}\text { Mulch } \\
\text { depth }(\mathrm{cm})\end{array}$ & \multicolumn{6}{|c|}{ Number and percent germination } & \multicolumn{5}{|c|}{ Shoot fresh weight (g) } \\
\hline \multirow[t]{5}{*}{ Above } & 0 & 11.3 & 29.8 & 22.5 & 23.8 & 87.5 & 58 & 1.3 & 7.5 & 4.5 & 3.6 & 16.9 \\
\hline & 0.6 & 4.2 & 3.3 & 7.8 & 13.7 & 29.0 & 19 & 0.6 & 3.4 & 3.7 & 5.3 & 13.1 \\
\hline & 1.3 & 0.0 & 0.2 & 0.2 & 1.0 & 1.3 & 1 & 0.0 & 0.0 & 0.0 & 0.1 & 0.1 \\
\hline & & $\mathrm{L}^{* * *} \mathrm{Q}^{* * *}$ & $\mathrm{~L}^{* * *} \mathrm{Q}^{* * *}$ & $\mathrm{~L}^{* * *} \mathrm{Q}^{* * *}$ & $\mathrm{~L}^{* * *} \mathrm{Q}^{* * *}$ & $\mathrm{~L}^{* * \star} \mathrm{Q}^{\star * *}$ & $\mathrm{~L}^{* * *} \mathrm{Q}^{* * *}$ & $\mathrm{~L}^{* * *} \mathrm{Q}^{*}$ & $\mathrm{~L}^{* * *} \mathrm{Q}^{\star}$ & $L^{* *}$ & $L^{* * *}$ & $\mathrm{~L}^{* * *} \mathrm{Q}^{* * *}$ \\
\hline & $\operatorname{LSD}_{0.05^{y}}$ & & 3.6 & 3.8 & 4.3 & 7.5 & & & 3.3 & 2.9 & 2.3 & 5.3 \\
\hline \multirow[t]{4}{*}{ Below } & 0 & 17.7 & 6.3 & 0.3 & 0.3 & 24.7 & 62 & 7.3 & 5.4 & 0.0 & 0.4 & 13.2 \\
\hline & 0.6 & 23.3 & 5.0 & 0.7 & 0.0 & 29.0 & 73 & 7.3 & 3.0 & 1.2 & 0.0 & 11.6 \\
\hline & & $L^{*}$ & NS & NS & NS & $L^{* * *}$ & $L^{* * *}$ & $\mathrm{~L}^{* *}$ & NS & NS & NS & $L^{* * *}$ \\
\hline & $\mathrm{LSD}_{0.05}$ & 7.8 & NS & NS & NS & 7.9 & 13.9 & 3.6 & NS & NS & NS & 6.2 \\
\hline
\end{tabular}

${ }^{2} \mathrm{~L}$ and $\mathrm{Q}$ represent linear and quadratic rate response to rice hull depth, respectively. ${ }^{*},{ }^{* *}$, or ${ }^{\star * *}$ represent significant rate responses at the $0.05,0.01$, or 0.001 level,

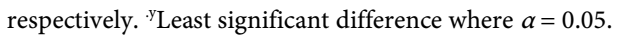


tainers seeded below the mulch layer compared to those above (16.3 vs. 3.9 seedlings, $P$ $<0.0001)$. A similar response with respect to both rice hull depth and seed placement was observed with flexuous bittercress shoot fresh weight.

Repeated measures analyses showed that flexuous bittercress numbers and shoot fresh weight when seeded above the mulch layer were affected by the interaction of time and rice hull depth $(P<0.0001)$ (Table 1$)$. Containers with $0.6 \mathrm{~cm}$ rice hulls had fewer established flexuous bittercress than non-mulched controls with the exception of 4 WAP. Despite reduced numbers, shoot fresh weights of bittercress with $0.6 \mathrm{~cm}$ rice hulls were similar to non-mulched controls with the exception of 8 WAP. Containers with 1.3 or $2.5 \mathrm{~cm}$ rice hulls had similar flexuous bittercress numbers and shoot fresh weight, and both were significantly lower than non-mulched controls or those with $0.6 \mathrm{~cm}$ rice hulls. No flexuous bittercress established throughout the experiment when seeded above $2.5 \mathrm{~cm}$ rice hulls, similar to results observed by Altland and Krause [8].

Weed numbers among containers with flexuous bittercress placed beneath the mulch changed over time $(P<0.0001)$. Flexuous bittercress numbers declined sharply from 4 to $8 \mathrm{WAP}$, as many of the applied 40 seed had germinated by the first harvest date. Flexuous bittercress numbers continued to decline over time in each treatment. There were no differences in bittercress number or shoot fresh weight with respect to rice hull depth from 8 to 16 WAP. Lack of differences among mulch treatments was due to there being relatively few bittercress germinating after the first harvest.

There was an interaction between seed placement and rice hull depth on percent establishment $(P<0.0001)$. Non-mulched controls in both groups had similar percent establishment (Table 1). Establishment decreased linearly and quadratically when seed were placed above the mulch, with lower establishment in $0.6 \mathrm{~cm}$ rice hulls compared to non-mulched controls. In contrast, establishment decreased linearly when seed were placed beneath the mulch layer with only the greatest rice hull depth reducing establishment below the non-mulched controls. At each rice hull depth (except nonmulched controls), establishment was lower when seed were placed above the mulch layer than when placed below the mulch layer.

At 4 WAP, creeping woodsorrel number and shoot fresh weight were affected by an interaction between seed placement and rice hull depth $(P<0.0001$; Table 2$)$. Creeping woodsorrel numbers decreased linearly and quadratically for those seeded above the rice hull mulch, and decreased linearly for those seeded below. Creeping woodsorrel numbers were greater when seeded below $0.6 \mathrm{~cm}$ rice hulls compared to above, while those seeded in 1.3 or $2.5 \mathrm{~cm}$ rice hulls were similar with respect to seed placement. Similar to results with flexuous bittercress at 4 WAP, weed numbers were higher in containers seeded below the rice hulls compared to those seeded above when averaged across rice hull depth (13.1 vs. 2.8 seedlings, $P=0.0001)$. Creeping woodsorrel shoot fresh weights at $4 \mathrm{WAP}$ had a similar response to numbers with respect to rice hull depth and seed placement.

Repeated measures analyses showed that rice hull depth and time interacted to affect 
Table 2. Creeping woodsorrel (Oxalis corniculata) numbers and shoot fresh weight 4, 8, 12, and 16 weeks after potting (WAP) in containers with 0 to $2.5 \mathrm{~cm}$ rice hull mulch. Weed seeds were placed either above or below the mulch layer. Weed seed placed above the mulch were applied at 10 seed per pot per week. Weed seeds placed below the mulch were applied at 40 seeds per pot prior to mulching.

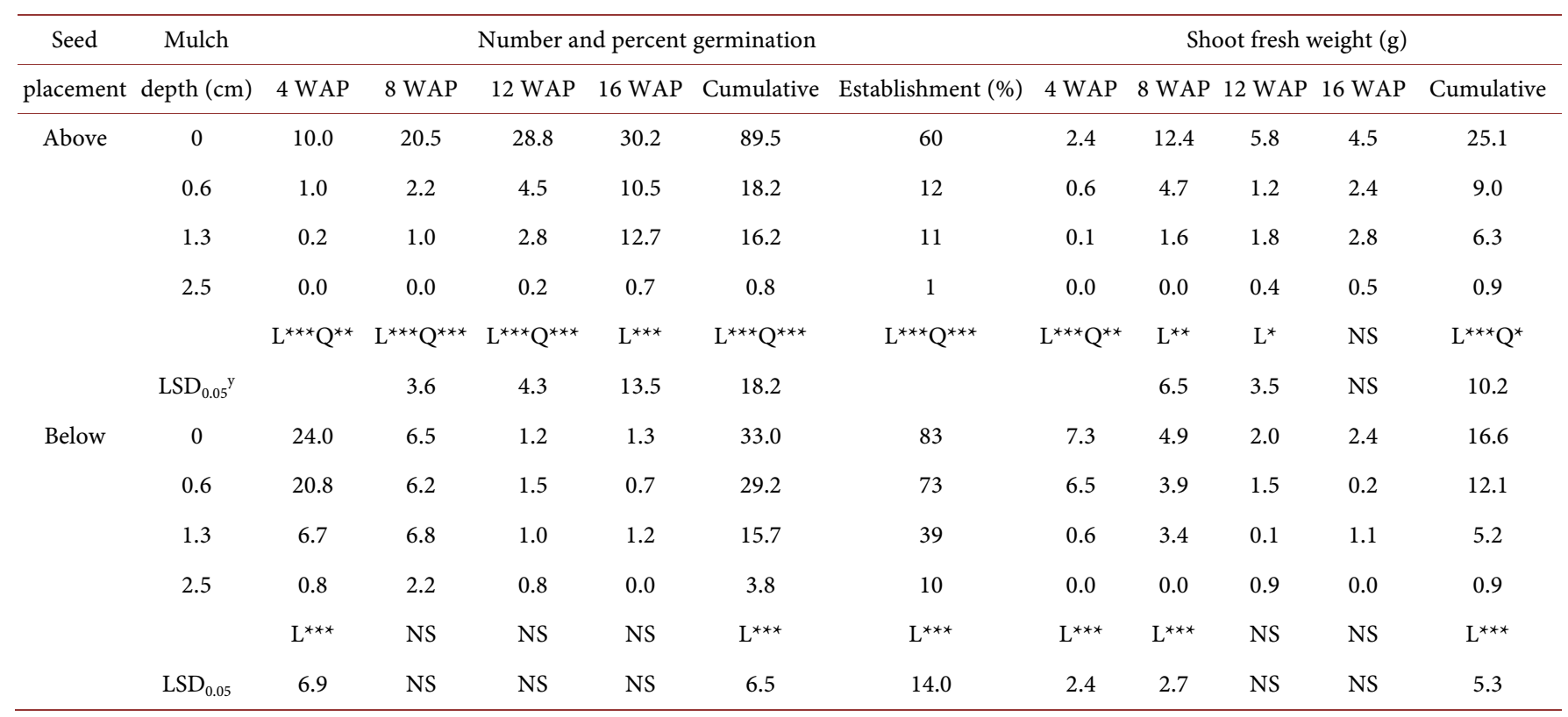

${ }^{z} \mathrm{~L}$ and $\mathrm{Q}$ represent linear and quadratic rate response to rice hull depth, respectively. ${ }^{*},{ }^{* *}$, or ${ }^{\star * \star}$ represent significant rate responses at the $0.05,0.01$, or 0.001 level, respectively. ${ }^{\mathrm{y}}$ Least significant difference where $\alpha=0.05$.

creeping woodsorrel number seeded above $(P=0.0454)$ and below the mulch $(P<$ 0.0001). Among containers seeded above the mulch, numbers increased from 4 to 16 WAP in non-mulched controls. Among these same treatments, all rice hull depths reduced creeping woodsorrel numbers compared to non-mulched controls, and there were no significant differences between those mulched with 0.6 to $2.5 \mathrm{~cm}$.

Among containers in which seed was placed beneath the rice hulls, creeping woodsorrel responded similar to flexuous bittercress over time. At 4 WAP, creeping woodsorrel numbers were higher in containers with 0 or $0.6 \mathrm{~cm}$ rice hulls compared to those with 1.3 or $2.6 \mathrm{~cm}$ rice hulls. From 8 to $16 \mathrm{WAP}$, there were no differences in creeping woodsorrel number from seed placed below the mulch layer. Shoot fresh weight had a similar response to rice hull depth and time as weed number.

Rice hull depth and seed placement affected percent creeping woodsorrel establishment (Table 2). Establishment decreased with increasing rice hull depth regardless of placement. Establishment was greater when seed were placed beneath the mulch layer at depths of 0 to $1.3 \mathrm{~cm}$, while establishment was similar above or below $2.5 \mathrm{~cm}$ rice hulls. .

\subsection{Light Penetration through Rice Hulls}

Light penetration through rice hulls decreased exponentially with increasing rice hull depth (Figure 1). A depth of only $0.3 \mathrm{~cm}$ rice hulls reduced $P A R$ by $97 \%$, while $0.6 \mathrm{~cm}$ reduced $P A R$ over $99 \%$ (Table 3). At depths ranging from 1.0 to $2.5 \mathrm{~cm}, 1 \mu \mathrm{mol} \cdot \mathrm{m}^{-2} \cdot \mathrm{sec}^{-1}$ or less $P A R$ penetrated the rice hull layer. Facelli and Pickett [9] showed a similar ex- 
Table 3. Average photosynthetically active radiation $(P A R)$ and light waveband penetration through varying depths of rice hull mulch. Spectral data recorded with a spectroradiometer beneath a clear glass plate with varying mulch depths placed above the glass.

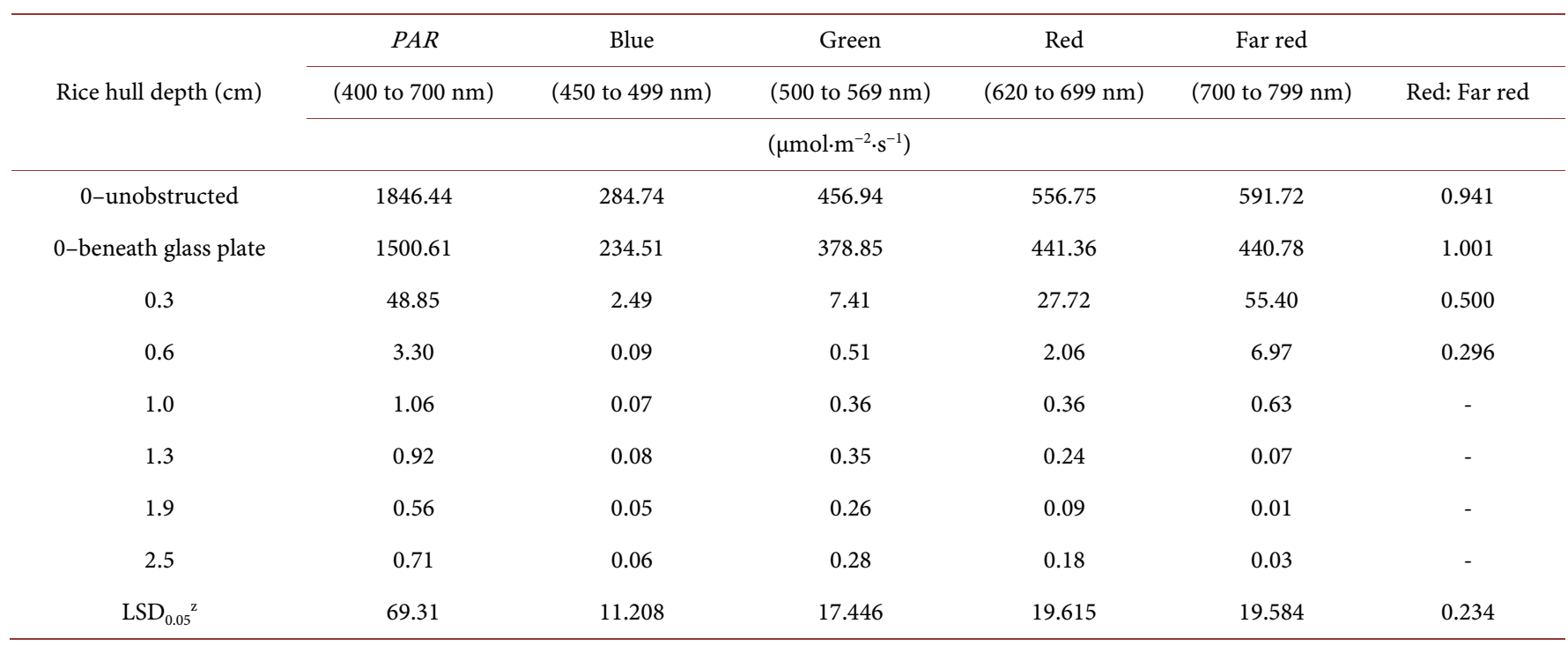

${ }^{\mathrm{z}}$ Least significant difference where $\alpha=0.05$.

ponential reduction in light transmission from litter of the annual grass Setaria faberi Herm., the perennial herb Solidago spp. (mostly $S$. Canadensis L.), and leaves of the hardwood tree Quercus alba L. All rice hull mulch depths reduced transmission of blue and green spectra below that which passed through the glass plate alone, and there were no differences among mulch depth $(>0 \mathrm{~cm})$ with respect to blue and green light intensity. Rice hulls selectively allowed greater penetration of light in the red to far red wavebands $(>600 \mathrm{~nm}$ ) (Figure 2). Red and far red light passing through $0.3 \mathrm{~cm}$ rice hulls was lower than that passing through the clear glass plate, but greater than at mulch depths $\geq 0.6 \mathrm{~cm}$. Teasdale and Mohler [10] likewise showed that light quality changed very little after passing through vetch (Vicia villosa Roth.) and rye (Secale cereale L.) cover crop residue on the soil surface, although there was slightly higher transmittance of spectra with higher wavelengths. The red to far red (R:FR) ratio decreased as the rice hull depth increased, from 0 (glass plate) to $0.6 \mathrm{~cm}$. The R:FR ratio was either unreliable or incalculable with depths greater than $0.6 \mathrm{~cm}$ due to the extremely low (or zero) detection of far red light at those depths. A decrease in R:FR ratio below 0.8 tends to inhibit germination in many weed species [11] [12].

\subsection{Germination Response to Light Level}

Flexuous bittercress germinated in Petri dishes at 1 WAS beneath all shade treatments (Table 4). Only seeds in complete darkness had lower germination than other treatments. By 3 WAS, percent germination increased quadratically from $0 \%$ to $88 \%$ shade, then decreased as shade increased from $88 \%$ to $100 \%$. Flexuous bittercress that germinated in $0 \%$ to $88 \%$ shade appeared to have true leaves of similar greenness and short internodes, with leaves emerging near or directly along the agar surface. At $99 \%$ shade, there were no true leaves; only cotyledons were present which were up to $0.5 \mathrm{~cm}$ in 

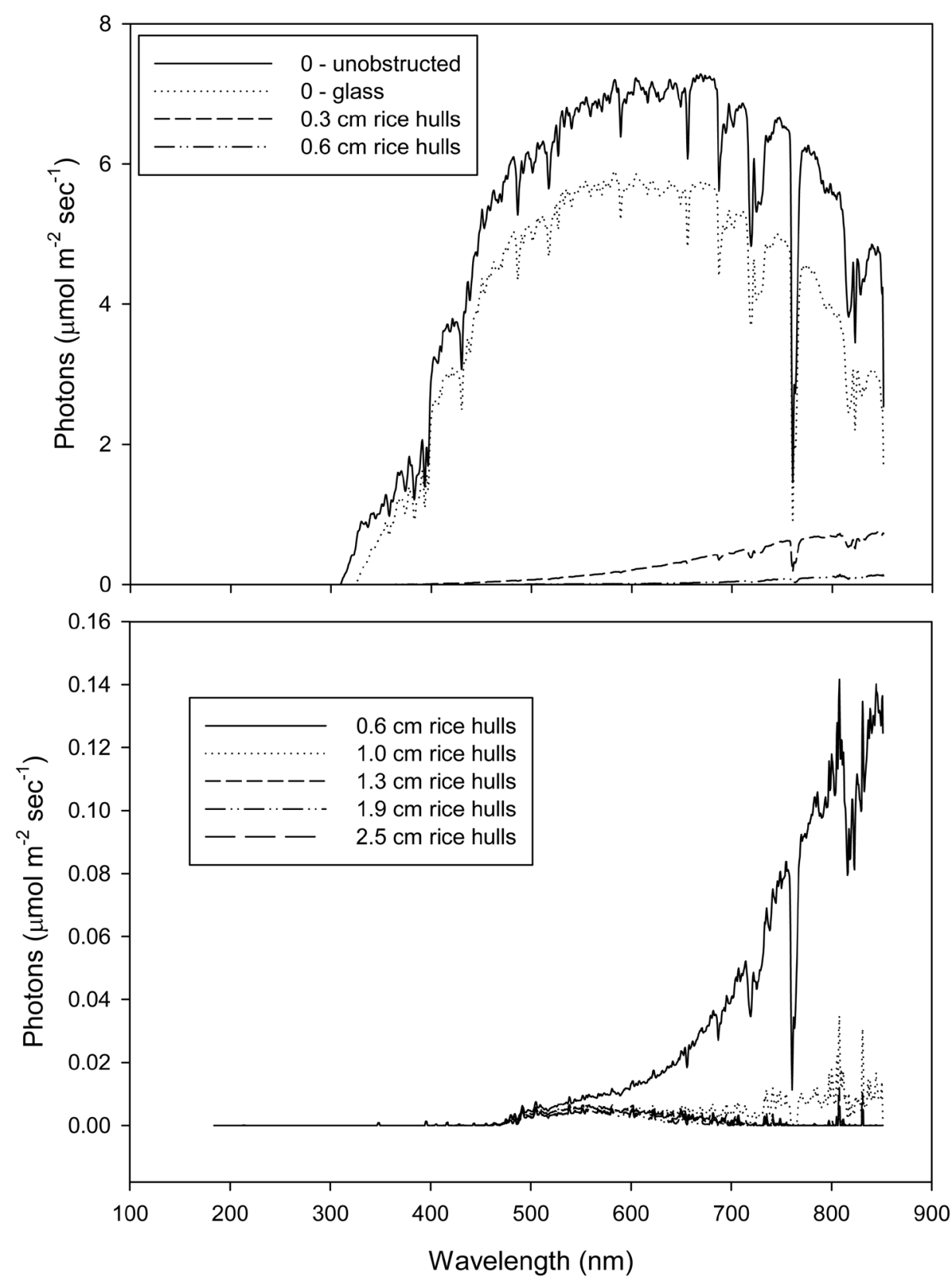

Figure 2. Spectral data of light penetrating through varying depths of rice hull mulch. The y-axis scale of the two charts differ, with the lower chart having a more magnified scale to better show the spectra of light penetrating the greater depths of rice hulls. Lines representing the spectra of light penetrating $0.6 \mathrm{~cm}$ of rice hulls are on both charts to serve as a visual reference between the two.

length and etiolated. At $100 \%$ shade, seedlings were etiolated, had elongated hypocotyls up to $1 \mathrm{~cm}$ in length, and yellow cotyledons.

At 1 WAS, creeping woodsorrel germination increased linearly from $0 \%$ shade up to 99\% shade (Table 4). Germination was lower in $100 \%$ shade compared to $99 \%$ shade. By 3 WAS, creeping woodsorrel germination was similar across all light treatments and 
Table 4. Percent germination of flexuous bittercress (Cardamine flexuosa) and creeping woodsorrel (Oxalis corniculata) in response to shade level and photosynthetically active radiation $(P A R)$ at 1 and 3 weeks after seeding (WAS) in a Petri dish with agar and a modified Hoagland solution.

\begin{tabular}{cccccc}
\hline \multirow{2}{*}{ Shade } & $P A R$ & \multicolumn{2}{c}{ Flexuous bittercress } & \multicolumn{2}{c}{ Creeping woodsorrel } \\
\cline { 3 - 5 } & & 1 WAS & 3 WAS & 1 WAS & 3 WAS \\
\hline 0 & $\mu \mathrm{mol} \cdot \mathrm{m}^{-2} \cdot \mathrm{sec}^{-1}$ & $(\%)$ & $(\%)$ & $(\%)$ & $(\%)$ \\
22 & 336.3 & 36 & 63 & 14 & 80 \\
61 & 261.6 & 26 & 76 & 22 & 96 \\
88 & 131.5 & 29 & 78 & 26 & 98 \\
99 & 41.3 & 34 & 90 & 40 & 96 \\
100 & 0.3 & 41 & 71 & 49 & 93 \\
LSD $_{0.05}{ }^{\mathrm{y}}$ & 0.0 & 8 & 13 & 16 & 90 \\
\hline
\end{tabular}

${ }^{z} \mathrm{NS}, \mathrm{Q}$, and L represent non-significant, quadratic, and linear response to shade level, respectively. ${ }^{*}$ or ${ }^{* * *}$ represent significant rate responses at the 0.05 or 0.001 level, respectively. ${ }^{\gamma}$ Least significant difference where $\alpha=0.05$.

averaged $92 \%$. This is in contrast to work by Holt [13] who reported decreased germination with decreased irradiance (from 0.25 to $25 \mu \mathrm{mol} \cdot \mathrm{m}^{-2} \cdot \mathrm{sec}^{-1} P A R$ ), and no germination in complete darkness. Creeping woodsorrel were visually larger in $0 \%$ to $61 \%$ shade treatments, with most seedlings having true leaves. Creeping woodsorrel in $88 \%$ to $99 \%$ shade had smaller and fewer true leaves, and those present were pale yellow in color. Those in $99 \%$ shade lacked true leaves, and had etiolated hypocotyls with green cotyledons. Seedlings in $100 \%$ shade were extremely etiolated (some greater than $3 \mathrm{~cm}$ long) with yellow cotyledons.

\subsection{Water Loss from Mulch Layers}

In Expt. 1, a greater percentage of water passed through rice hulls than peat moss at the initiation (week 0) of the experiment (Table 5). By week 2, a greater percentage passed through rice hulls than both pine bark and peat moss. By 4 weeks, there were no differences in the percent of applied irrigation water that passed through the mulches. By this point, the pine bark and peat moss appeared to be visually saturated and unable to hold additional water applied at irrigation, thus a high percent of the applied water passed through these mulch layers later in the experiment. A similar trend occurred in Expt. 2 with respect to percent of water passing through the mulches. Throughout both experiments, rice hulls allowed for $88 \%$ to $96 \%$ of the applied irrigation to pass through the mulch layer.

In both experiments, rice hulls retained less water than pine bark and peat moss at each time point following irrigation in which water content was determined, and at every week data was collected (Table 5 ). In both experiments, pine bark retained more water than peat moss at week 0 (with the exception of hour 4 in Expt. 2). This was un- 
Table 5. The percent of water that passed through a $2.5 \mathrm{~cm}$ thick pine bark, peat moss, or rice hull mulch layer, and the volume of water retained within the mulch layer, after an application of approximately $1.2 \mathrm{~cm}$ of water from irrigation. Data was collected at 0,2 , and 4 weeks after initiating the experiment.

\begin{tabular}{|c|c|c|c|c|c|c|c|c|c|c|c|}
\hline & & \multicolumn{5}{|c|}{ Experiment 1} & \multicolumn{5}{|c|}{ Experiment 2} \\
\hline & & \multicolumn{6}{|c|}{ Volume of water retained } & \multicolumn{4}{|c|}{ Volume of water retained } \\
\hline \multicolumn{2}{|c|}{ Week Mulch type } & $\begin{array}{l}\text { Water passed } \\
\text { through mulch }\end{array}$ & $0 \mathrm{hr}$ & $1 \mathrm{hr}$ & $4 \mathrm{hr}$ & $24 \mathrm{hr}$ & $\begin{array}{l}\text { Water passed } \\
\text { through mulch }\end{array}$ & $0 \mathrm{hr}$ & $1 \mathrm{hr}$ & $4 \mathrm{hr}$ & $24 \mathrm{hr}$ \\
\hline & & $(\%)$ & & $(\mathrm{m}$ & & & (\%) & & $(\mathrm{m}$ & & \\
\hline \multirow[t]{4}{*}{0} & Pine bark & 69 & 138 & & 130 & 96 & 64 & 147 & 139 & 116 & 96 \\
\hline & Peat moss & 53 & 120 & & 104 & 79 & 43 & 128 & 121 & 106 & 79 \\
\hline & Rice hulls & 89 & 26 & & 20 & 14 & 88 & 29 & 25 & 18 & 15 \\
\hline & $\operatorname{LSD}_{0.05}{ }^{\mathrm{z}}$ & 23 & 9 & & 19 & 8 & 18 & 8 & 6 & 14 & 5 \\
\hline \multirow[t]{4}{*}{2} & Pine bark & 75 & 145 & 136 & 124 & 73 & 92 & 172 & 161 & 147 & 119 \\
\hline & Peat moss & 68 & 158 & 147 & 135 & 81 & 87 & 159 & 151 & 139 & 112 \\
\hline & Rice hulls & 90 & 54 & 48 & 44 & 34 & 96 & 65 & 58 & 53 & 48 \\
\hline & $\mathrm{LSD}_{0.05}$ & 13 & 8 & 8 & 8 & 9 & 6 & 10 & 9 & 9 & 9 \\
\hline \multirow[t]{4}{*}{4} & Pine bark & 77 & 142 & 134 & 122 & 72 & 89 & 169 & 160 & 149 & 126 \\
\hline & Peat moss & 87 & 173 & 166 & 155 & 101 & 86 & 164 & 173 & 144 & 122 \\
\hline & Rice hulls & 91 & 64 & 58 & 49 & 31 & 92 & 68 & 60 & 53 & 43 \\
\hline & $\mathrm{LSD}_{0.05}$ & NS & 10 & 9 & 9 & 8 & NS & 9 & 29 & 8 & 7 \\
\hline
\end{tabular}

${ }^{z}$ Least significant difference where $\alpha=0.05$. NS means non-significant.

expected considering one of the most important characteristics of peat moss is its capacity to absorb and internally retain large quantities of water. The amount of water held by peat moss can be 15 to 20 times its own weight, depending on peat moss type [14]. By week 4, water retention was equal or greater in peat moss compared to pine bark across both experiments. Greater water retention by pine bark early in the experiment was likely due to initial hydrophobicity common in sphagnum peat moss. As the experiment progressed over time with daily irrigation events, this initial hydrophobicity was overcome and peat moss retained a greater volume of water compared to pine bark.

The layer of mulch within the round Buchner funnels of this experiment was disc-shaped with a height of $2.5 \mathrm{~cm}$, diameter of $13.1 \mathrm{~cm}$, and volume of $342 \mathrm{~cm}^{3}$. Thus volumetric water content (VWC) in each mulch layer could be calculated for the volumes of water retained listed in Table 3. Pine bark and peat moss VWC ranged from 0.40 to $0.50 \mathrm{~cm} \cdot \mathrm{cm}^{-1}$ at hour 0 throughout the two experiments, and decreased to 0.2 to $0.4 \mathrm{~cm} \cdot \mathrm{cm}^{-1}$ by hour 24 . In contrast, VWC in rice hulls never exceed $0.20 \mathrm{~cm} \cdot \mathrm{cm}^{-1}$ at hour 0 and declined to less than $0.10 \mathrm{~cm} \cdot \mathrm{cm}^{-1}$ by hour 24 in the experiment. O'Meara et al. [15] used hydrangea ( $H$. macrophylla "Fasan") and gardenia ( $G$. jasminoides "Radicans") in a pine bark substrate to show that the ability of plants to extract water from a soilless substrate is species-dependent, and for these two species transpiration declined 
at VWC of 0.20 to $0.28 \mathrm{~cm} \cdot \mathrm{cm}^{-1}$ and slowed to near zeroonce VWC dropped below 0.12 to $0.16 \mathrm{~cm} \cdot \mathrm{cm}^{-1}$

\section{Discussion}

Rice hulls do not exclude enough light at depths of $2.5 \mathrm{~cm}$ to prevent bittercress or creeping woodsorrel germination. The amount of $P A R$ penetrating rice hulls from 0.6 to $2.5 \mathrm{~cm}$ averaged $1.3 \mu \mathrm{mol} \cdot \mathrm{m}^{-2} \cdot \mathrm{sec}^{-1}$. While flexuous bittercress germination declined when PAR dropped below $41.3 \mu \mathrm{mol} \cdot \mathrm{m}^{-2} \cdot \mathrm{sec}^{-1}$, germination still occurred in complete darkness. Creeping woodsorrel had $92 \%$ germination across all light levels. Numbers and shoot fresh weights of both species decreased with increasing rice hull depth when seed were placed beneath the mulch layer. The mechanism of this control is not likely due to light reduction or light exclusion, especially with creeping woodsorrel. It is widely accepted that germination rate of seed decreases with increasing burial depth [16]. Decreasing numbers and shoot fresh weights with increasing rice hull depth in our study was likely a function of burial depth as well.

A meta-analysis of seedling recruitment in natural grasslands found that plant litter up to $500 \mathrm{~g} \cdot \mathrm{m}^{-2}$ improved seedling recruitment, while greater litter amounts $(>500$ $\mathrm{g} \cdot \mathrm{m}^{-2}$ ) inhibited seedling recruitment [17]. Teasdale and Mohler [18] showed a similar response in germination of four weed species beneath various mulch materials over a silt loam soil. The mass of rice hulls applied in our experiment was $46 \mathrm{~g}$ at a depth of $2.5 \mathrm{~cm}$ in a $15 \mathrm{~cm}$ diameter container, resulting in an application equivalent to 2523 $\mathrm{g} \cdot \mathrm{m}^{-2}$. Cumulative germination and shoot fresh weights of the flexuous bittercress and creeping woodsorrel in our experiment were reduced at 1.3 and $2.5 \mathrm{~cm}$ depths (equivalent to 1250 and $2500 \mathrm{~g} \cdot \mathrm{m}^{-2}$, respectively), but not reduced at $0.6 \mathrm{~cm}$ depth $\left(625 \mathrm{~g} \cdot \mathrm{m}^{-2}\right)$. Flexuous bittercress and creeping woodsorrel establishment beneath rice hull mulch seem to follow the general rule of seedling establishment beneath litter proposed by Loydi et al. [17]. Altland and Krause [8] speculated that gaps in the mulch barrier common with applications of $0.6 \mathrm{~cm}$ rice hulls were responsible for greater establishment of liverwort and bittercress; however, it is likely that lack of rice hull mass also contributes to poor control.

Flexuous bittercress cumulative numbers that established from beneath the $2.5 \mathrm{~cm}$ rice hull layer was reduced $68 \%$ relative to the non-mulched control. Likewise, cumulative shoot fresh weights of these bittercress were reduced $78 \%$ compared to the nonmulched control. In contrast, creeping woodsorrel numbers and shoot fresh weight from beneath $2.5 \mathrm{~cm}$ rice hulls was reduced $88 \%$ and $94 \%$, respectively, compared to non-mulched controls. Flexuous bittercress seed used in this study were $0.9 \pm 0.13 \mathrm{~mm}$ long and $0.6 \pm 0.06 \mathrm{~mm}$ wide ( $\mathrm{n}=10$ seeds), while creeping wood sorrel were larger with length of $1.4 \pm 0.14 \mathrm{~mm}$ and width of $1.0 \pm 0.05 \mathrm{~mm}(\mathrm{n}=10)$. Others have shown decreasing sensitivity to mulch depth with larger seed [18] [19]. Thus it was somewhat surprising that the larger seed of creeping woodsorrel were more affected by burial depth than the smaller-seeded bittercress.

Rice hulls retain less water than pine bark or peat moss, and this seems to be the 
primary mechanism by which rice hulls provide weed control when seeds are applied to the mulch surface. Weed seed can germinate in soils with water potential as low as -1.5 $\mathrm{MPa}$, as summarized by Bullied et al. [20]. Although seed germination as a function of water tension has not been established in soilless substrates, tensions as low as -1.5 $\mathrm{MPa}$ are well below the critical threshold for easily available water $(-5 \mathrm{kPa})$ in soilless substrates [21]. Furthermore, Hagen et al. [22] showed that photosynthetic rate (Pn) in oakleaf hydrangea (Hydrangea quercifolia "Alice") declines to near zero below 0.2 $\mathrm{cm} \cdot \mathrm{cm}^{-1}$ VWC. Niu et al. [23] reported Pn of six species of bedding plants varied according to VWC, but Pn was at or near zero when VWC was between 0.10 and 0.15 $\mathrm{cm} \cdot \mathrm{cm}^{-1}$. While the VWC for germination of weed seed in soilless substrates has not been established, the VWC of the rice hull mulch layer in this study is at or below the level that has been shown as necessary to sustain plant growth.

Flexuous bittercress and creeping woodsorrel disseminate seed with a ballistic dispersal mechanism. A closely related bittercress species, hairy bittercress ( $C$. hirsuta), can project seeds from 1 to $5 \mathrm{~m}$ [24] [25]. Oxalis seed dispersal from the mother plant can occur up to $2 \mathrm{~m}$ [26]. Weed seeds entering a container via any of these dispersal mechanisms would be analogous to the weed seeds placed on top of the mulch in our experiment. Seeds placed on top of the rice hull mulch surface $(1.3$ to $2.5 \mathrm{~cm})$ failed to germinate or establish at a high level.

Seed present on the substrate surface at the time of mulch application are not controlled as well as those introduced after rice hull application. This may be a limitation to the use of rice hulls for weed control. Based on these results and that of previous research [8], rice hulls used as a mulch should be applied to recently potted, weed-free container crops at a depth of 1.3 to $2.5 \mathrm{~cm}$. Rice hulls applied to previously infested containers, even if containers are carefully hand-weeded to remove existing weeds, may be less effective even at depths of $2.5 \mathrm{~cm}$ due to the inability of rice hulls to exclude light from reaching the substrate surface and the ability of flexuous bittercress and creeping woodsorrel to germinate beneath and successfully establish through the rice hull layer.

\section{Acknowledgements}

This research was in part funded by the Floriculture Nursery Research Initiative and the Horticulture Research Institute.

\section{References}

[1] Moore, B.A., Larson, R.A. and Skroch, W.A. (1989) Herbicide Treatment of Container-Grown "Gloria" Azaleas and "Merritt Supreme" Hydrangeas. Journal of the American Society for Horticultural Science, 114, 73-77.

[2] Cole, J.C., Maggard, A.O., Will, R.E. and Hennessey, T.C. (2012) Tree-Based Mulches and Their Leachate Suppress Weed Seed Emergence. Journal of Environmental Horticulture, 30, 146-149.

[3] Penny, G.M. and Neal, J.C. (2003) Light, Temperature, Seed Burial, and Mulch Effects on Mulberry Weed (Fatoua villosa) Seed Germination. Weed Technology, 17, 213-218. http://dx.doi.org/10.1614/0890-037X(2003)017[0213:LTSBAM]2.0.CO;2 
[4] Cochran, D.R., Gilliam, C.H., Eakes, D.J., Wehtje, G.R., Knight, P.R. and Olive, J. (2009) Mulch Depth Affects Weed Germination. Journal of Environmental Horticulture, 27, 85-90.

[5] Richardson, B., Gilliam, C.H., Fain, G.B. and Wehtje, G. (2008) Nursery Container Weed Control with Pinebark Mini-Nuggets. Journal of Environmental Horticulture, 26, 144-148.

[6] Wilen, C.A., Schoch, U.K. and Elmore, C.L. (1999) Mulches and Subirrigation Control Weeds in Container Production. Journal of Environmental Horticulture, 17, 174-180.

[7] Ferguson, J., Rathinasabapathi, B. and Warren, C. (2008) Southern Redcedar and Southern Magnolia Wood Chip Mulches for Weed Suppression in Containerized Woody Ornamentals. Hort Technology, 18, 266-270.

[8] Altland, J.E. and Krause, C. (2014) Parboiled Rice Hulls in Containers Reduces Liverwort and Flexuous Bittercress Growth. Journal of Environmental Horticulture, 32, 59-63.

[9] Facelli, J.M. and Pickett, S.T.A. (1991) Plant Litter: Light Interception and Effects on an Old-Field Plant Community. Ecology, 72, 1024-1031. http://dx.doi.org/10.2307/1940602

[10] Teasedale, J.R. and Roth, C.L. (1993) Light Transmittance, Soil Temperature, and Soil Moisture under Residue of Hairy Vetch and Rye. Agronomy Journal, 85, 673-680. http://dx.doi.org/10.2134/agronj1993.00021962008500030029x

[11] Taylorson, R.B. and Borthwick, H.A. (1969) Light Filtration by Foliar Canopies: Significance for Light-Controlled Weed Seed Germination. Weed Science, 17, 48-51.

[12] Teasdale, J.R. and Daughtry, C.S. (1993) Weed Suppression by Live and Desiccated Hairy Vetch (Vicia villosa). Weed Science, 41, 207-212.

[13] Holt, J.S. (1987) Factors Affecting Germination in Greenhouse-Produced Seeds of Oxalis corniculata, a Perennial Weed. American Journal of Botany, 74, 429-436. http://dx.doi.org/10.2307/2443818

[14] Puustjarvi, V. and Robertson, R.A. (1975) Physical and Chemical Properties. In: Robinson, D.W. and Lamb, J.G.D., Eds., Peat in Horticulture, Academic Press, London, 23-38.

[15] O'Meara, L., Chappell, M.R. and Van Iersel, M.W. (2014) Water Use of Hydrangea macrophylla and Gardenia jasminoides in Response to a Gradually Drying Substrate. HortScience, 49, 493-498.

[16] Chancellor, R.J. (1964) The Depth of Weed Seed Germination in the Field. Proceedings of the 7 th British Weed Control Conference, 7, 607-613.

[17] Loydi, A., Eckstein, R.L., Otte, A. and Donath, T.W. (2013) Effects of Litter on Seedling Establishment in Natural and Semi-Natural Grasslands: A Meta-Analysis. Journal of Ecology, 101, 454-464. http://dx.doi.org/10.1111/1365-2745.12033

[18] Teasdale, J.R. and Mohler, C.L. (2000) The Quantitative Relationship between Weed Emergence and the Physical Properties of Mulches. Weed Science, 48, 385-392. http://dx.doi.org/10.1614/0043-1745(2000)048[0385:TQRBWE]2.0.CO;2

[19] Buhler, D.D., Mester, T.C. and Kohler, K.A. (1996) The Effect of Maize Residues and Tillage on Emergence of Setaria faberi, Abutilon theophrasti, Amaranthus retroflexus and Chenopodium album. Weed Research, 36, 153-165. http://dx.doi.org/10.1111/j.1365-3180.1996.tb01811.x

[20] Bullied, W.J., Bullock, P.R. and Van Acker, R.C. (2012) Modelling Soil Water Retention for Weed Seed Germination Sensitivity to Water Potential. Applied and Environmental Soil Science, 2012, Article ID: 812561. http://dx.doi.org/10.1155/2012/812561

[21] De Boodt, M. and Verdonck, O. (1972) The Physical Properties of the Substrates in Horticulture. Acta Horticulturae, 26, 37-44. http://dx.doi.org/10.17660/ActaHortic.1972.26.5 
[22] Hagen, E., Nambuthiri, S., Fulcher, A. and Geneve, R. (2014) Comparing Substrate Moisture-Based Daily Water Use and On-Demand Irrigation Regimes for Oakleaf Hydrangea Grown in Two Container Sizes. Scientia Horticulturae, 179, 132-139.

http://dx.doi.org/10.1016/j.scienta.2014.09.008

[23] Niu, G., Rodriguez, D.S. and Wang, Y. (2006) Impact of Drought and Temperature on Growth and Leaf Exchange of Six Bedding Plant Species under Greenhouse Conditions. HortScience, 41, 1408-1411.

[24] Bachman, G. and Whitwell, T. (1994) Hairy Bittercress (Cardamine hirsuta) Seed Production and Dispersal in the Propagation of Landscape Plants. Proceedings of the Southern Nursery Association Research Conference, 39, 299-302.

[25] Vaughn, K.C., Bowling, A.J. and Ruel, K.J. (2011) The Mechanism for Explosive Seed Dispersal in Cardamine hirsuta (Brassicaceae). American Journal of Botany, 98, 1276-1285. http://dx.doi.org/10.3732/ajb.1000374

[26] Doust, L.L., MacKinnon, A. and Doust, J.L. (1985) Biology of Canadian Weeds. 71. Oxalis stricta L., O. corniculsta L., $O$. dillenii Jacq. ssp. dillenii and $O$. dillenii Jacq. ssp. filipes (Small) Eiten. Canadian Journal of Plant Science, 65, 691-709.

http://dx.doi.org/10.4141/cjps85-090

\section{Submit or recommend next manuscript to SCIRP and we will provide best service} for you:

Accepting pre-submission inquiries through Email, Facebook, LinkedIn, Twitter, etc. A wide selection of journals (inclusive of 9 subjects, more than 200 journals)

Providing 24-hour high-quality service

User-friendly online submission system

Fair and swift peer-review system

Efficient typesetting and proofreading procedure

Display of the result of downloads and visits, as well as the number of cited articles

Maximum dissemination of your research work

Submit your manuscript at: http://papersubmission.scirp.org/

Or contact ajps@scirp.org 